\title{
Vampire and Empire: Dracula and the Imperial Gaze ${ }^{1}$
}

\section{Stu Burns}

\author{
Editor, Fine Lines creative writing journal
}

\begin{abstract}
Bram Stoker's 1897 novel Dracula was enmeshed in the discourse of British Imperialism, both in its composition and its reception. Stoker drew on Imperial-era studies to lend his narrative verisimilitude, including material on history, folklore, and geography from all over the world. As the range of Orientalist studies grew going into the twentieth century, Dracula effectively became part of imperial discourse, both in its own portrayal of the exotic, dangerous East and for its association with the vampire motif that recurred in colonialist texts. This paper will examine the context of Dracula and vampiric tropes in imperialist rhetoric, focusing on the literature and ethnography of regions specifically cited in the novel. These include Britain's tropical colonies in Malaysia and India, as well as the Empire's sphere of influence in China. Special attention will be paid to the power relations inherent in the "imperial gaze," as well as European fears of reverse colonialism and, more acutely, the problems of mimetic desire and "going native."
\end{abstract}

Keywords: Dracula (novel), Bram Stoker, Vampires, British Empire, Orientalism

Ike many confronted with combat and its effect on the human psyche, physician George

Stoker returned to England from the Russo-Turkish War and wrote a book. In charge of the Ottoman Red Crescent ambulance service, the young Irishman was as enmeshed in the conflict as any war surgeon might have been. That said, his inspiration to write sprung more from the cultures around him than from the carnage that he treated. His 1878 war memoir is essentially a travel narrative. In the tradition of British imperial writers, George Stoker acts as a surveyor of foreign character, subjecting the peoples around him to what is often called the "imperial gaze" (Ashcroft, Griffiths, \& Tiffin, 2001, p. 84). As he explains, I have had ample opportunities of judging the various nationalities who inhabit European and Asiatic Turkey, of ascertaining, from personal observation and experience, their leading characteristics; and I now propose giving my readers a slight sketch of what the

\footnotetext{
${ }^{1}$ An earlier version of this paper appeared in European Studies Conference Selected Proceedings (2011). Special thanks to my friends in the Omaha Writers League for their help preparing this draft.
} 
eTropic 16.1 (2017): 'Tropical Liminal: Urban Vampires \& Other Bloodsucking Monstrosities’ Special Issue I 6

conclusions are which I have arrived at with regard to these people with whom I have come in contact (as cited in Cain, 2006, p. 107).

George Stoker's sketch of the Bulgarian peasants is harsh. In his view, "the typical Bulgarian...is given to strong drink and, as a rule, a liar and a cheat" (as cited in Cain, 2006, p. 110). He observes the Bulgarians destroying their own relief hospitals in retribution for not being employed to build them. When staying in Bulgarian villages, Stoker is offended at having to bed down with the families of local officials while he battles rodents for floor space and chokes down spoiled food (Cain, 2006, p. 111). The region's Jewish and Armenian money-changers are portrayed as filthy and slovenly, pleading poverty while skimming coins from their transactions (Cain, 2006, p. 115). Indeed, the only people Stoker deems worthy are the gallant Turks, though this may be a product of the Ottoman alliance with fellow empire-builder Britain as opposed to racial even-handedness. From a twenty-first century perspective, George Stoker's time abroad did not engender an enlightened compassion for the poverty of people who had been Ottoman subjects for the better part of five centuries. Rather, regional poverty was a result of poor character, and benevolent avoidance was the doctor's prescription. This is reinforced through his memoir's title: With "The Unspeakables" (Stoker, 1878).

George Stoker's appraisal of the territory beyond Britain's European pale was not lost on his older brother, Bram. George lived with Bram and his wife while writing his memoir, and the elder Stoker edited his brother's work. Some biographers cite With "The Unspeakables" as one of Bram Stoker's primary cultural sources for his seminal vampire story, Dracula (Belford, 1996, p. 128; Cain, 2006, p. 119). In most places, the iconic gothic novel shares George Stoker's contempt of the region, acknowledging that travelling beyond Budapest was tantamount to "leaving the West and entering the East” (Stoker, 1997 [1878], p. 9). As Bram Stoker writes in Dracula:

It seems to me that the further east you go the more unpunctual are the trains. What ought they to be in China? [...] The women looked pretty, except when you got near them, but they were very clumsy about the waist. [...]The strangest figures we saw were the Slovaks, who were more barbarian than the rest, with their big cow-boy hats, great baggy dirty-white trousers, white linen shirts, and enormous heavy leather belts, nearly a foot wide, all studded over with brass nails. They wore high boots, with their trousers tucked into them, and had long black hair and heavy black moustaches. They are very picturesque, but do not look prepossessing. On the stage they would be set down at once as some old Oriental band of brigands. They are, however, I am told, very harmless and rather wanting in natural self-assertion (Stoker, 1997 [1878], p. 11).

This example finds Bram Stoker playing the familiar Orientalist role as defined by cultural critic Edward Said (1994 [1978]). To paraphrase, the "Oriental" (as Said defines it, this term can apply to practically any group under imperial examination) is irrational, depraved, childlike, and intrinsically "different." The European, specifically the Briton in Stoker's case, is the binary opposite: rational, virtuous, mature, and normal (Said, 1994 [1987], p. 40). This was familiar territory for English writers of Stoker's day, both in their consideration of emerging Eastern 
eTropic 16.1 (2017): 'Tropical Liminal: Urban Vampires \& Other Bloodsucking Monstrosities' Special Issue I 7

European nationalities and in their discourse regarding Britain's own overseas empire. The traditional view of the British Empire's mission was a benevolent one. The Empire was a civilizing force taking up Rudyard Kipling's "White Man's Burden" to bring the savage, immature globe into the modern industrial world (Said, 1994 [1978], pp. 226-227). ${ }^{2}$ Less charitably, as David Spurr (1993) puts it, imperialist writers habitually debased the peoples of the colonies, portraying them as passive, decadent, and, as Spurr paraphrases Charles Darwin, limited to an amoral "social instinct" in order to rationalize conquest and domination (pp. 79-81). In Said's more nuanced analysis, writers from imperialist nations, through their descriptions of world cultures, shored up their own positions by rhetorically fabricating this duality. As Said puts it:

"Knowledge of the Orient, because generated out of strength, in a sense creates the Orient, the Oriental, and his world....The Oriental is depicted as something one judges (as in a court of law), something one studies and depicts (as in a curriculum), something one disciplines (as in a school or prison), something one illustrates (as in a zoological manual)....Orientalism, then, is knowledge of the Orient that places things Oriental in class, court, prison, or manual for scrutiny, study, judgment, discipline, or governing" (1994, pp. 40-41).

Dracula, published in 1897 when Britain was nearing her high water mark of global hegemony, shared shelf space with imperial compilations like James G. Frazer's (1890) The Golden Bough and Richard Burton's (1885-1888) translation of The Book of the Thousand Nights and a Night. Conversely, Britain and the other colonial powers established schools to educate colonial peoples in the ways of industrial Europe, often with great success. As Hungarian Anglophile scholar Arminius Vambery wrote, "a swarthy-looking Asiatic quoting Shakespeare, Virgil, and Homer is an extraordinary, but not unusual, spectacle" (as cited in Cain, 2006, p. 102). ${ }^{3}$ Vambery's tone asserts the unequal dichotomy of colonial education: when imperial peoples learn about "Asiatic" language, culture, and geography, that knowledge is used to transform those from whom it is learned. When colonial peoples learn about European literature and British engineering, that knowledge transforms the learners.

Film theorist E. Ann Kaplan defines the imperial gaze as "gaze structures specific to representing ethnic Others" (1997, p. 60). Among these structures are "the assumption that the white western subject is central" and the failure to understand that other peoples "have integral cultures and lives that work according to their own, albeit different, logic." Displaced into the "condescending paternalism" of the imperial gaze is an anxiety over how fragile the "master" position is (Kaplan, 1997, p. 78). One of the great fears inherent in the imperial process is the possibility - or inevitability - of its inversion (Kaplan, 1997, pp. 78-79). As Jacques Lacan maintained when developing his theory of the gaze, the observer may think they are in control of the process of observing, but when the observer realizes that the object of their examination is looking back at

\footnotetext{
${ }^{2}$ Kipling was writing to encourage the United States, but the phrase certainly applies to British attitudes.

${ }^{3}$ It is worth noting that Vambery was an associate of Stoker's, and is best known by horror aficionados as a minor character in Dracula.
} 
eTropic 16.1 (2017): 'Tropical Liminal: Urban Vampires \& Other Bloodsucking Monstrosities' Special Issue I 8

them, they see the fragility of their situation and how easily that control can be lost (Felluga, 2011). This is an explicit threat in Dracula. The protagonist of the early chapters, Jonathan Harker, is surprised to find that the Count has made an extensive survey of British culture and geography. Though the Count is already a fluent English speaker, he detains Harker at his Transylvanian castle for a month, ostensibly to refine his speech so that Dracula can pass for an Englishman. As the novel progresses, Dracula grills Harker on English legal procedure, and Harker notes, at first with appreciation, that his host has a comprehensive collection of English literature and geographical works. It eventually becomes clear that the charming familiarity with European culture that Arminius Vambery noted has been horribly inverted, and the exotic foreigner plans to use this knowledge to exploit British weaknesses just as the British had exploited their overseas empire (as well as Stoker's native Ireland). ${ }^{4}$

More insidious than the fear of overt reverse colonization is the persistent trope of Europeans losing their cultivated identities and "going native." British apprehension about white men and women abandoning the culture of their upbringing in favour of the exotic ways of the colonized is conspicuous in the discourse of the period. For example, Joseph Conrad's (1899) classic imperial novel Heart of Darkness gives us Mr. Kurtz, a talented, ambitious European who loses his moral compass and takes on the "nasty, brutish, and short" life of an African warlord. As Patrick Brantlinger puts it, "Kurtz's dying words, 'The horror! The horror!' may refer to death or to African savagery, but they undoubtedly also refer to his own backsliding from civilization -in other words, to his going native" $(2011$, p. 68$)$. Along the same lines, Henry Morton Stanley's memoirs of his 1870s African campaigns remarked, in Stanley's own inimitably racist tone, that "no matter how valiant a man be in his intentions when he sets out to govern the blatant wooly-headed rabble of his colony; he will be prostrated before the unconquerable lassitude which the climate quickly engenders in him as soon as he sets foot on its shores" (as cited in Spurr, 1993, pp. 79-81). Since Stanley's solution to the seductive languor of African life was to impose a beyond-Draconian kleptocratic slave state in the Belgian Congo at the behest of King Leopold, the rhetorical power of this threat had obvious real-world consequences. ${ }^{5}$ Conversely, it was not unknown for Europeans to adopt "Oriental" ways by mimesis - taking on aspects of colonial culture by desire as opposed to by temptation. As Thomas Babington Macaulay wrote, British commander Robert Clive "became himself an Indian intriguer" to establish the British Empire in South Asia (Brantlinger, 2011, p. 73). ${ }^{6}$ This approach scandalized English society, however, when successful East India Company officials returned home with their adoption of Indian culture in evidence. As

\footnotetext{
${ }^{4}$ A discussion of these dynamics can be found in Stephen Arata's (1990) 'The Occidental tourist: Dracula and the anxiety of reverse colonization.' On Stoker's Irish roots as reflected in Dracula, see Joseph Valente's (2001) Dracula's Crypt: Bram Stoker, Irishness, and the Question of Blood.

${ }^{5}$ An overview of Stanley and Leopold's depredations in the Congo can be found in any African history textbook. A particularly accessible work is Adam Hochschild's (1998), King Leopold's ghost: A story of greed, terror, and heroism in colonial Africa.

${ }^{6}$ For a more thorough treatment of this sort of mimesis, see the treatment of Erich Auerbach's work in Catherine Gallagher and Stephen Greenblatt's (2000), Practicing new historicism, pp. 31-47.
} 
eTropic 16.1 (2017): 'Tropical Liminal: Urban Vampires \& Other Bloodsucking Monstrosities' Special Issue I 9

Horace Walpole put it, "What is England now? A sink of Indian wealth, filled by nabobs [a derisive term for nouveau riche Englishmen who made their money in Asia] and emptied by Macaronis!" (as cited in Brantlinger, 2011, p. 72). The idea of Europeans losing themselves in the "darkness" of the colonial world was a very keenly-felt fear in Stoker's Britain, and it remains a part of Dracula's (at times) counter-intuitive appeal.

The influence of Eastern European vampire legends on Dracula is obvious, and has been thoroughly covered in critical literature. ${ }^{7}$ Conversely, Dracula's relationship to folklore from the tropics and other regions of the British Empire has not been interrogated nearly as well, either in terms of the novel's composition or its reception. Stoker acknowledges the global nature of vampire folklore in Dracula's text, where we find lead vampire hunter Professor Van Helsing counselling his team that the vampire "is known everywhere that men have been. In old Greece, in old Rome, he flourish in Germany all over, in France, in India, even in the Chersonese, and in China, so far from us in all ways, there even is he, and the peoples for him at this day" (Stoker, 1997 [1878], p. 211). Stoker repeated this list of vampire homelands almost verbatim in an interview for British Weekly (Miller, 2009, p. 276). Though Dracula's author was probably not the exhaustive scholar that some critics have made him out to be (Miller, 2000), Stoker was obviously aware of vampire folklore's global proliferation and the resonance the exotic undead had with an audience already ill at ease with the unintended consequences of building a world empire.

This resonance tracked with the popularity of Dracula and the growth of vampire legends in popular consciousness. Indeed, in contrast to the life cycle of most novels, Dracula did not do blockbuster business on its 1897 publication. Its reception that year was certainly solid, but the book's popularity grew over time as popular concerns about the state of the Empire grew, becoming a popular sensation in post-World War I English-speaking countries as the British Empire reached its zenith. At the height of the Empire, Stoker's novel inspired an amazingly successful stage play by Hamilton Deane and John L. Balderston. The elaborate production premiered in Britain in 1924, initially in downscale vaudeville houses before making the jump to the more prosperous West End in February of 1927. A revised American version, starring Bela Lugosi, opened on Broadway that fall, earning two million dollars in thirty-three weeks and prefiguring the story's well-known film treatments (Deane, Balderston, \& Skal, 1993).

Dracula's popularity, both as novel and as play, was mirrored in the nonfiction world by the sensational writings of Montague Summers, whose 1928 compilation The Vampire: His Kith and Kin reached an enduring audience. In a ranging style reminiscent of James G. Frazer (or, less

\footnotetext{
${ }^{7}$ Nearly every thorough study of Dracula or vampire folklore makes some effort to connect the novel (and subsequent adaptations to stage and screen) to Eastern European legends. One early study along these lines was Raymond T. McNally and Radu Florescu's (1972), In search of Dracula: A true history of Dracula and vampire legends; McNally and Florescu's (admittedly cursory) work has been thoroughly challenged by Elizabeth Miller (2000), Dracula: Sense and nonsense. An original take on Slavic folklore and its influence on Western vampire fiction is Bruce McClelland's (2006), Slayers and their vampires: A cultural history of killing the dead.
} 
eTropic 16.1 (2017): ‘Tropical Liminal: Urban Vampires \& Other Bloodsucking Monstrosities' Special Issue I 10

charitably, Aleister Crowley), ${ }^{8}$ Summers brings together stories of vampires and vampire-like creatures from European histories, Classical works, and Orientalist studies (Summers, 2011 [1928]). He also resurrects anecdotes about supposed vampire precursors like premature burial, necrophilia and cannibalism. Summers' work is perhaps deliberately obtuse, with blocks of untranslated Greek, Latin, French, and German. Summers own life was something of an example of the paradoxical fascination and apprehension that English audiences felt regarding vampires. He was a learned translator and philologist, compiling new editions of Restoration dramas and the notorious witchfinder's guide Malleus Maleficarum. At the same time, his writings betray his credulous fear of the vampire. As he wrote in his successive work, The Vampire in Europe, "That a large number of cases of vampirism must be accounted certain only the most prejudiced will deny" (Summers, 2014 [1929], p. x). For all their eccentricity, Summers' books were standard references for vampire folklore through the end of Britain's imperial period (Cohen, 1989, p. 287). Like Dracula, they have never been out of print, even though the author's supernatural beliefs were (ostensibly) well outside the mainstream opinion of his audience (Melton, 2011, pp. 680682).

The vampire's prominence in the Anglophone mentality grew throughout the imperial period, signified by the growing popularity of Stoker's novel, the successful play in the 1920s, and the generous reception of Montague Summers' arcane collections. I would argue that this indicates a parallel growth in concern over reverse colonialism and mimetic desire as the British Empire developed and the lives of English families entwined with those of peoples they had so long tried to keep subservient and distant. For the remainder of this paper, I will concentrate on the body of vampire traditions that appear in selected studies of countries within the British Empire's sphere of influence, with an emphasis on the regions singled out by Stoker, their historical context, and the reception of these new undead characters in European discourse.

Bram Stoker's mention of the "Chersonese" is ambiguous. The term has been applied to several places throughout history, including both Gallipoli and the Crimea. Indeed, some commentators have identified Dracula's Chersonese with the tip of the Balkan Peninsula - understandably, given the novel's setting (Stoker, 1993, p. 289). Bram Stoker's own notes, however, place his Chersonese squarely in the tropics. Specifically, the text refers to present-day Malaysia, a territory administered by the East India Company since the early 1800s and formally governed by Britain after a series of violent conflicts in the 1870s (James, 1994, pp. 244-247; Stoker, 2008, pp. 206209). Stoker copied an excerpt from Isabella Bird's 1883 travel book The Golden Chersonese and the Way Thither that dealt with Malaysia's "universal belief" in a plethora of supernatural creatures, including the Pelisit, a woman who died in childbirth and returns as a large bird to menace infants. The travel narrative also tells of a blood-drinking owl, the Polong, who acts as a

${ }^{8}$ Rosemary Ellen Guiley, "A New Introduction" in Montague Summers, John Edgar Browning, ed., The Vampire: His Kith and Kin: A Critical Edition (Berkeley: The Apocryphile Press, 2011), xix-xxvii. 
eTropic 16.1 (2017): 'Tropical Liminal: Urban Vampires \& Other Bloodsucking Monstrosities' Special Issue I 11

familiar to Malay magicians. Finally, Bram Stoker copied down Bird's account of the Penanggalan, a demon that possesses women and makes living vampires of them (Stoker, 2008, pp. 206-209).

In 1900, while Dracula was still building its reputation, British anthropologist Walter William Skeat compiled a more comprehensive survey of Malay folk tradition, paying special attention to some of the vampiric creatures that Isabella Bird reported and including more detail. (Skeat, 1900, pp. 320-331). Skeat's (1990) accounts of the Pelesit and the Polong differ from Bird's writings. The tales Skeat collected still portray the Polong as an imp that exchanges magical assistance for blood. The Pelesit of Skeat's compendium, however, is a tamer household spirit, usually in the form of a cricket that the magical Polong can tame and use as a sort of understudy. Skeat's Penanggalan is similar to Bird's in that it is a female vampire that attacks children, but Skeat says nothing of demon possession. Rather, his Penanggalan is a more fanciful creature who came into being by accidentally kicking herself in the chin so hard that her head flew off. The disembodied head went on to become a vampire, squeezing through roofs and floors trying to suck the blood of new-borns (Skeat, 1900, pp. 327-331).

Skeat adds two poignant vampires to the mix. The first is the Langsuir, a mother who dies either in childbirth or in the forty days after and returns to suck the blood of children. The Langsuir's child is another undead creature of Malay folklore. Called the Pontianak, it is also a blood-seeker that preys on children. Like the Pelesit in Bird's accounts, the Langsuir is a flying undead creature. She coasts through the air, screaming like the Irish banshee, seeking the blood of the living. The Langsuir is fond of fish, and is often blamed for stealing good catches from fishermen. Skeat's Langsuir was a beautiful woman who died in childbirth. When her stillborn infant morphed into the Pontianak, the Langsuir (seemingly shocked back to life by the horror) clapped her hands and flew away screaming. She still displays great beauty, wearing a flowing green robe and boasting ankle-length black hair along with dazzling long fingernails. The cruel irony is that the beautiful black hair hides a hole in the back of her neck that she uses to suck children's blood. To prevent their undead return, women who died in childbirth were usually buried with marbles in their mouths to stifle the deathly screams. A bittersweet twist on the Langsuir is that she could be rehabilitated: if one cut her long nails and hair and stuffed them down the hole in her throat, she would become a normal woman and live out the rest of her life as if she were never undead. The twist in this redemptive belief is that the reformed Langsuir must never be allowed to dance, or she would revert to her ghastly form and fly back into the night (Skeat, 1900, pp. 325-327).

Skeat does not elaborate on the Pontianak's appearance, other than to say that it is probably derived from the screech owl like its mother. The apotropaics Skeat names to keep a stillborn child from becoming a Pontianak are similar to those used against the Langsuir: "a hen's egg is put under each armpit, a needle in the palm of each hand, and (probably) glass beads or some simple equivalent in its mouth" (Skeat, 1900, p. 327). Interestingly enough, the Pontianak is often referred to as a Jinn, the magical species often transliterated as "genie" that has its own dedicated Surah in the Qur'an (Al-Jinn, 72). In another touch of connectivity with Muslim tradition, the 
eTropic 16.1 (2017): ‘Tropical Liminal: Urban Vampires \& Other Bloodsucking Monstrosities' Special Issue I 12

incantations used to subdue the Pontianak rely heavily on the invocation of Allah. Readers of The Thousand Nights and One Night may recall that calling on Allah works with Scheherazade's ghouls as well (Burton, 1885, pp. 54-60; Skeat, 1900, p. 327).

Examined with the advantage of twenty-first century scholarship, Skeat's widely-disseminated version of Langsuir and Pontianak folklore demonstrates how colonial discourse generated knowledge about tropical cultures with only a nascent apprehension of cultural - and literal vocabulary. In contemporary Malay culture, as Nur "Adlina Maulod explains, the term "Pontianak" almost always refers to the entity Skeat calls the "Langsuir", and depictions of the Pontianak as the spectre a woman who died in childbirth is ubiquitous in present-day Malay popular media and folklore. Maulod offers possible explanations for Skeat's interpretation, including an erroneous etymology of Pontianak as "dead child" resulting from a misunderstanding of Malay syntax, as well as the suggestion that, in some communities, "Langsuir" and "Pontianak" are interchangeable, and the overwhelming use of "Pontianak" today is due to language shift and standardization over the intervening century, with no small debt to the Pontianak's depiction in the cinema. In sum, as Maulod puts it, Skeat's ethnography, though undertaken with care and respect, "should not be regarded as an authoritative source of knowledge but rather an introduction" pending a deeper immersion in the field (Maulod, 2009, pp. 17-21). ${ }^{9}$

The British Empire's dealings with China had a long and venerable history. China was one of the few non-western countries to be respected by European thinkers during the Enlightenment, and learning Chinese culture was considered a virtue, not a warning sign of a weak-willed person going native. By the 1830s, however, Britain's more aggressive incursions into China had led to a harder attitude more typical of European imperialism. In order to keep China's opium and tea markets open, Britain fought two wars with China between 1839 and 1860, formally acquiring Hong Kong and informally assuming an imperial role in the rest of the country until 1895, when China's government went into a political free fall and Britain allowed concessions in various major Chinese cities to the other European powers (James, 1994, pp. 235-244). Like other parts of the world, China was awash in missionaries and imperial functionaries as it entered the Twentieth Century.

In 1927, Theosophist spiritual seeker Walter Evans-Wentz published a translation of the Tibetan text Bardo Thodol, a core work on the afterlife in Tibetan Buddhism, as The Tibetan Book of the Dead, the first of four Buddhist scriptures the American mystic would publish. In describing the eighth through fourteenth day of the afterlife, Evans-Wentz's translation maintained that fifty-eight blood drinking deities, wrathful and cloaked in flame, would come to challenge the devotee. They would be drinking blood from shells, wearing dried human heads as jewellery, and wielding human corpses as clubs. The worldly would flee in terror, falling into suffering. The enlightened ones, however, would recognize the blood-drinking as a symbol of sangsaric existence, i.e., attachment

${ }^{9}$ Thanks to eTropic Editor Anita Lundberg for suggesting this critique of Skeat, as well as Dillon \& Lundberg, (this issue) for providing the source material. 
eTropic 16.1 (2017): 'Tropical Liminal: Urban Vampires \& Other Bloodsucking Monstrosities' Special Issue I 13

to earthly life that springs from their own psyche. By recognizing that the blood-drinking deities are unreal and powerless, the adept may proceed toward enlightenment (Evans-Wentz, 2000, pp. 131-142). As Donald S. Lopez, Jr. (2000) writes, the first volume:

...seems to have originated in another age. All four books assume the undifferentiated dichotomy of the materialist West and the mystic East, and East that holds the secret to the West's redemption. Few of the concerns of scholars - such as language or culture or history-are to be found in the books. Instead, the volumes are presented as repositories of a timeless wisdom preserved by the East, a wisdom that will someday save the West, ultimately overcoming the duality of the hemispheres to culminate in the Unity of Mankind. This apparently beatific vision has since been shown to be the product of a romantic Orientalism that viewed the traditions of Asia as a natural resource to be extracted and refined for the consumption of the West; the books thus mark a moment in the history of colonialism (pp. A-B).

Lopez's (2000) description aligns well with E. Ann Kaplan's (1997) commentary on the imperial gaze. Westerners did not want to know the Other or to be with the Other. At best, they may have wanted to see what they could learn from the Other for their own ends. In his critique, Lopez explains that the translation Evans-Wentz organized from the work of Tibetan scholars (who did not critique the final draft) was considerably influenced by Evans-Wentz's own Theosophical viewpoint. Lopez does not comment on the blood-drinking deities and the impact that phasing would have had when The Tibetan Book of the Dead was published. However, it may bear some consideration that Evans-Wentz was using vampiric metaphors just as Dracula was making its Broadway premiere.

Taking a less esoteric approach, one of the most impressive Western studies of Chinese religious and folk tradition from the period was Leiden University sinologist Jan de Groot's 1892 five-volume Religious System of China. In the detailed study, de Groot goes into some detail about the jiang shi, a Chinese undead very similar to the Slavic vampire. The jiang shi was usually a product of improper funeral rites, such as allowing a corpse direct contact with sunlight or moonlight. Along these lines, extended times between death and burial put a body in danger of joining the undead (De Groot, 1892, pp. 106-107). ${ }^{10}$ This neglect allowed the basest of the six souls in traditional belief to take over the body. To prevent this, de Groot writes, coffins would be covered with oiled paper and the house cleansed spiritually. If these preventatives failed, the resulting creature would break out of its coffin at night and attack people, usually draining their blood within seconds. Like their Slavic counterparts, Chinese vampires did not decompose, and their bodies were bloated with blood (De Groot, 1892, pp. 738-740). They were easily recognizable by the long white hair covering their body and their long, talon-like fingernails. The preferred way to kill a jiang shi was by cremating the body and the coffin. De Groot also cites stories of frying the creature in

${ }^{10}$ Jiang shi is the Pinyin transliteration. De Groot's unique transliteration of the term is kiang si; the WadeGiles transliteration is chiang shih. 
eTropic 16.1 (2017): 'Tropical Liminal: Urban Vampires \& Other Bloodsucking Monstrosities' Special Issue I 14

a large pan, though he admits that this is fanciful and doubts that anyone ever tried to saute their local vampire (De Groot, 1892, p. 107). ${ }^{11}$

The best-known jiang shi story is a traditional tale from Shandong Provence. Four weary travellers come to a house begging a place to sleep. The old man who lived there consented after some persuasion, but the only room he could offer was the parlour where his daughter-in-law's body lay in state while her husband was out finding a proper coffin. Three of the travellers fell asleep quickly, and just as the fourth was dozing off, he heard the creak of the corpse rising from the couch. The corpse went to each of those sleeping, breathing on them. The one person awake, paralyzed with fear, held his breath as the daughter approached, then lay still as she returned to her place. He tried to sneak from the room, but the jiang shi jumped upright and chased him down the road to a monastery where morning prayers were beginning. She cornered the traveller against a tree and made a mad grab for him. He collapsed to the ground in a dead faint and the jiang shi missed him, ramming her fingernails into the tree. Just then dawn broke, and the jiang shi reverted to her state of unmoving rigor mortis (De Groot, 1892, pp. 734-738). Though the jiang shi can also be a sort of ghostly lover or a more innocuous dancing corpse, this story's chase motif is the most common type of Chinese vampire story; de Groot's compilation also includes undead bandits chasing the unwary and nocturnal predators draining the blood of innocent wives doing household chores. De Groot relates some hearsay that, in some parts of China, fear of the jiang shi is so pronounced that corpses are laid out until they are thoroughly decomposed before burial (pp. 738-748). Other means of avoiding or destroying the jiang shi besides immolation include stealing the lid of its coffin, strewing rice, red peas, and bits of iron around its coffin while the undead is out on a prowl, and driving seven jujube stones into the corpse's spine (pp. 748752). De Groot shows his folkloristic chops in noting that blood-sucking jiang shi were unknown before vampire folklore became popular in 1700s Western Europe, subtly implying that this aspect of the vampire may have been transmitted by the Europeans (p. 745). ${ }^{12}$ Intriguingly enough, de Groot refers to European vampire folklore as a thing of the past, noting that the undead "excited the whole of Europe...during the preceding century" (1892, p. 106). Given Stoker's reference to Chinese folklore as a jumping-off point for Dracula, de Groot's ethnography may have been a factor in the vampire's Western popular culture revival.

As noted above, the academic literature on Britain's Empire in India and the resulting cultural exchange is extensive. The British East India Company gradually gained effective control of the country in the 1600s, and it remained a highly-studied, closely held colony until after World War II. By the time of the British Empire, India did not have an active vampire folklife like Malaysia or China; available sources do not indicate widespread use of anti-vampire apotropaics there. India

\footnotetext{
${ }^{11}$ In Vampires, burial and death, Paul Barber (1989, p. 119) speculates that the idea of long white hair covering the jiang shi may reflect the observation of fungus growing on disinterred corpses.

${ }^{12}$ For details on the Eighteenth-Century "vampire epidemic" in Europe, see David Keyworth's (2006), 'Was the vampire of the eighteenth century a unique type of undead-corpse?' and Gabor Klaniczay's (1987), 'Decline of witches and rise of vampires in 18th century Habsburg monarchy'.
} 
eTropic 16.1 (2017): 'Tropical Liminal: Urban Vampires \& Other Bloodsucking Monstrosities' Special Issue I 15

did sport an active literary tradition of vampiric creatures, however. One of the most well-known pieces of Indian literature is the Baital-Pachisi, named for the vampire-like Baital, an evil spirit that roamed the earth possessing dead bodies. The legendary English Orientalist Sir Richard Burton translated Baital-Pachisi in 1870, giving it the English title Vikram and the Vampire and paraphrasing "Baital" as "the Vampire" throughout. As Burton tells the story, the brave Raja Vikram seeks out Baital in a cemetery in order to help a Hindu yogi perform powerful magic. Baital evades Vikram's attempts to capture him, however, hanging just outside the warrior's reach. When Vikram finally snares the "vampire," Baital begins telling him various stories that spin together much in the same fashion as Burton's The Book of the Thousand Nights and a Night, ending each story with a riddle that, if solved, means the end of Baital's captivity and a failure for the raja. Baital never attacks anyone through the epic, remaining a character in the framing story. His description is aptly horrific, however. Baital is a skeletal figure holding a bat in his toes. He hangs from a tree limb above a fire that doesn't burn. At the conclusion of the book, Vikram is finally able to bring Baital to the yogi, and the resulting ritual sees the yogi summon many of the great Hindu figures, including the vampiric goddess Kali, who predict a long and prosperous reign for the hero (Burton, 1992 [1870]).

Kali herself might also be viewed as a figure in the world vampire folklore consumed by Imperial Britain. Venerated in both mainland India and, especially, tropical Sri Lanka, Kali is perhaps bestknown in Hindu literature for her role in the Devi-Mahatmya, a secondary Hindu scripture where she appears as the goddess Devi's fury incarnate. In episode three of this epic, Devi is facing the seemingly invincible Raktabija who, when wounded, forms new incarnations of himself from the drops of his blood when they touch the ground. Kali emerges from Devi's forehead and ferociously drinks the blood from Raktabija's wounds before it can touch the ground (McDermott \& Kripal, 2003). Kali's horrific appearance, including a belt and necklace of human heads and fangs that would rival any Dracula film, sent shivers through many English observers, many of whom unfairly associated her with Indian Thugee bandits. Though her horrific appearance belies Kali's more nuanced reputation among those with a deeper understanding of her role in Hindu spiritual life, it is fair to say that tales of a widely-worshipped goddess with jet black hair and blood dripping from her perpetually outstretched tongue was probably enough to make many Britons reconsider their position abroad.

An exhaustive study of vampire-like figures in British imperial discourse would examine the ethnography of territories that Bram Stoker did not directly reference. This would include vampire folklore in the tropical South Pacific Islands, Australia, and Africa just to begin (Melton, 2011, pp. 5-6; Summers, 2011 [1928], pp. 258-259). The point is that British readers were treated to a generous buffet of "real" vampires from Britain's overseas sphere of influence, many of whom made Dracula seem tame. For the most part, these studies were conventional invocations of the imperial gaze, casting colonial people as "objects" to be studied by more rational "subjects" who were, with the exception of outliers like Montague Summers, not believers in undead terrors stalking the living in search of blood. At the same time, however, there was the lurking paranoia 
eTropic 16.1 (2017): 'Tropical Liminal: Urban Vampires \& Other Bloodsucking Monstrosities' Special Issue I 16

and dread of the gaze inverted. Vampire tales from the colonies were part of the same discursive field as Dracula, emphasizing the elements of danger and mystery inherent in the colonial process and giving face to ideas of reverse colonialism and the perils of "going native." The steady stream of powerful, exotic vampire stories that poured into the English-speaking world through the Empire's apex fuelled Dracula's growth from a modestly received novel into a ubiquitous archetype through all popular media. To consider Dracula is to consider the culture of imperialism and the imperial gaze in all its manifestations, including those that are grossly, subtly, and chillingly monstrous.

\section{References}

Arata, S. (1990). The occidental tourist: Dracula and the anxiety of reverse colonization. Victorian Studies, 33(4), 621-645.

Ashcroft, B., Griffiths, G., \& Tiffin, H. (2001). Post-colonial studies: The key concepts. New York, NY: Routledge.

Barber, P. (1989). Vampires, burial, and death. New Haven, CT: Yale University Press.

Belford, B. (1996). Bram Stoker: A biography of the author of Dracula. New York, NY: Alfred A. Knopf.

Brantlinger, P. (2011). Taming cannibals: Race and the Victorians. Ithaca, NY: Cornell University Press.

Burton, R. F. (1885-1888). The book of the thousand nights and a night: $A$ plain and literal translation of the Arabian Nights (Vols. 1-17). London: The Burton Club.

Burton, R. F. (1992) Vikram and the vampire: Classic Hindu tales of adventure, magic and romance. Rochester, VT: Park Street Press. (Original work published in 1870).

Bird, I. (2010). The golden chersonese and the way thither. New York, NY: Cambridge University Press. (Original work published in 1883).

Cain, J. E., Jr. (2006). Bram Stoker and Russophobia: Evidence of the British fear of Russia in Dracula and The Lady of the Shroud. Jefferson, NC: McFarland.

Cohen, D. (1989). The encyclopedia of monsters. New York, NY: Dorset Press.

De Groot, J. (1892). The religious system of China (Vols. 1-5). Leiden: E.J. Brill.

Deane, H., \& Balderston, J., \& Skal, D. (Eds). (1993). Dracula: The ultimate, illustrated edition of the worldfamous vampire play. New York, NY: St. Martin's Press.

Evans-Wentz, W. Y., (Ed.). (2000). The Tibetan book of the dead, or the after-death experiences on the Bardo Plane, according to Lama Kazi Dawa-Samdup's English rendering. Oxford: Oxford University Press, 2000. (Original work published in 1927).

Felluga, D. (2011). Introduction to Jacques Lacan: Module on the gaze [web page]. Retrieved from: http://www.cla.purdue.edu/english/theory/psychoanalysis/lacangaze.html

Gallagher, C., \& Greenblatt, S. (2000). Practicing new historicism. Chicago, IL: The University of Chicago Press.

Hochschild, A. (1998). King Leopold's ghost: A story of greed, terror, and heroism in colonial Africa. Boston, MA: Mariner Books.

James, L. (1994). The rise and fall of the British empire. London: Abacus.

Kaplan, E. A. (1997). Looking for the other: Feminism, film, and the imperial gaze. New York, NY: Routledge.

Keyworth, D. (2006). Was the vampire of the eighteenth century a unique type of undead-corpse? Folklore, $117(3), 241-260$. 
eTropic 16.1 (2017): 'Tropical Liminal: Urban Vampires \& Other Bloodsucking Monstrosities' Special Issue I 17

Klaniczay, G. (1987). Decline of witches and rise of vampires in $18^{\text {th }}$ century Habsburg monarchy. Ethnologia Europaea, 17, 165-180.

Maulod, N. A. (2009). The haunting of Fatimah Rock: History, embodiment and spectral urbanism in Singapore (Master's thesis). Retrieved from: http://scholarbank.nus.edu.sg/handle/10635/17340

McClelland, B. (2006). Slayers and their vampires: A cultural history of killing the dead. Ann Arbor, MI: University of Michigan Press.

McDermott, R. F., \& Kripal, J.J. (2003). Encountering Kali: In the margins, at the center, in the west. Berkeley, CA: University of California Press.

McNally, R. \& Florescu, R. (1972). In search of Dracula: A true story of Dracula and vampire legends. Greenwich, CT: New York Graphic Society.

Melton, J. G. (2011). The vampire book: The encyclopedia of the undead ( $3^{\text {rd }}$ ed.). Canton, MI: Visible Ink.

Miller, E. (Ed.). (2009). Bram Stoker's Dracula: A documentary journey into vampire country and the Dracula phenomenon. New York, NY: Pegasus Books.

Miller, E. (2000). Dracula: Sense and Nonsense. Westcliff-on-Sea: Desert Island Books.

Said, E. (1994). Orientalism: Western conceptions of the Orient. New York, NY: Vintage Books. (Original work published in 1978).

Skeat, W. W. (1900). Malay magic: Being an introduction to the folklore and popular religion of the Malay Peninsula. London: MacMillan and Co.

Spurr, D. (1993). The rhetoric of empire: Colonial discourse in journalism, travel writing, and imperial administration. Durham, NC: Duke University Press.

Stoker, B. (2008). Bram Stoker's notes for Dracula: A facsimile edition (R. Eighteen-Bisang, \& E. Miller, Eds.). Jefferson, NC: McFarland \& Company.

Stoker, B. (1997). Dracula: A Norton critical edition (N. Auerbach, \& D.J. Skal, Eds.). New York, NY: W.W. Norton and Co.

Stoker, B. (1993). The essential Dracula (L. Wolf, Ed.). New York, NY: Plume Books.

Stoker, G. (1878). With "The Unspeakables;" or, two years' campaigning in European and Asiatic Turkey. London: Chapman and Hall.

Summers, M. (2011). The vampire: His kith and kin: A critical edition (J.E. Browning, Ed.). Berkeley, CA: The Apocryphile Press. (Original work published in 1928).

Summers, M. (2014). The vampire in Europe: A critical edition (J.E. Browning, Ed.). Berkeley, CA: The Apocryphile Press. (Original work published in 1929).

Valente, J. (2001). Dracula's crypt: Bram Stoker, Irishness, and the question of blood. Urbana, IL: University of Illinois Press. 